\title{
Parent Experience with False-Positive Newborn Screening Results for Cystic Fibrosis
}

\author{
Hayeems RZ, Miller FA, Barg CJ, Bombard Y, Kerr E, Tam K, \\ Carroll JC, Potter BK, Chakraborty P, Davies C, Milburn J.
}

Version Post-print/accepted manuscript

Citation Hayeems RZ, Miller FA, Barg CJ, Bombard Y, Kerr E, Tam K, Carroll (published version) JC, Potter BK, Chakraborty P, Davies C, Milburn J. Parent Experience With False-Positive Newborn Screening Results for Cystic Fibrosis. Pediatrics. 2016 Sep 1;138(3):e20161052.

Additional publisher The final version of this article is available from The American information Academy of Pediatrics at https://doi.org/10.1542/peds.2016-1052.

Copyright/License Copyright (C) 2016 by the American Academy of Pediatrics

How to cite TSpace items

Always cite the published version, so the author(s) will receive recognition through services that track citation counts, e.g. Scopus. If you need to cite the page number of the author manuscript from TSpace because you cannot access the published version, then cite the TSpace version in addition to the published version using the permanent URI (handle) found on the record page.

This article was made openly accessible by $U$ of $T$ Faculty. Please tell us how this access benefits you. Your story matters. 


\section{Parent Experience with False Positive Newborn Screening Results for Cystic Fibrosis}

Robin Z. Hayeems $P h D^{1,2 *}$ Fiona A. Miller PhD ${ }^{2,}$ Carolyn J. Barg MSc ${ }^{2}$, Yvonne Bombard PhD ${ }^{2,3,}$ Elizabeth Kerr PhD ${ }^{4,5}$, Karen Tam ScM ${ }^{6,}$ June C. Carroll MD ${ }^{7}$, Beth K. Potter PhD ${ }^{8,}$

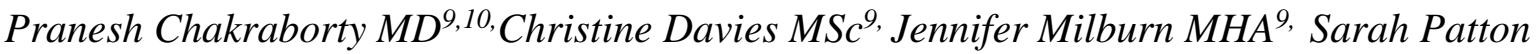
$M A^{2}$, Jessica P. Bytautas $M s c,{ }^{2,11}$, Louise Taylor $N P^{21}$,April Price $M D^{13}$, Tanja Gonska $M D^{12}$, Katherine Keenan BSc ${ }^{12}$ Felix Ratjen MD,PhD ${ }^{5,12,14}$ Astrid Guttmann MDCM, MSc ${ }^{1,2,5,12,15}$

1. Child Health Evaluative Sciences, Research Institute, The Hospital for Sick Children, Toronto, Canada

2. Institute of Health Policy, Management and Evaluation, University of Toronto, Canada

3. Li Ka Shing Knowledge Institute of St. Michael's Hospital, Toronto, Canada

4. Department of Psychology, The Hospital for Sick Children, Toronto, Canada

5. Department of Pediatrics, Faculty of Medicine, University of Toronto, Canada

6. Division of Clinical and Metabolic Genetics, The Hospital for Sick Children, Toronto, Canada

7. Department of Family and Community Medicine, Sinai Health System, University of Toronto, Canada

8. School of Epidemiology, Public Health \& Preventive Medicine, Faculty of Medicine, University of Ottawa, Ottawa, Canada

9. Newborn Screening Ontario, Children's Hospital of Eastern Ontario, Ottawa, Canada

10. Department of Pediatrics, Faculty of Medicine, University of Ottawa, Ottawa, Canada

11. Department of Public Health, University of Helsinki, Helsinki, Finland

12. Division of Pediatric Medicine, The Hospital for Sick Children, Toronto, Canada

13. Children's Hospital Of Western Ontario, London, Ontario, Canada

14. Division of Respiratory Medicine, Department of Pediatrics, The Hospital for Sick Children, Toronto, Canada

15. Institute for Clinical Evaluative Sciences, Toronto, Canada

*Corresponding author:

Robin Hayeems, $\mathrm{PhD}$

Scientist-track Investigator, Child Health Evaluative Sciences

Hospital for Sick Children Research Institute

Assistant Professor, Institute of Health Policy Management and Evaluation

University of Toronto

686 Bay Street, 11.9710

Toronto, ON M5G 0A4 Canada

Phone: 416-813-7654*309259

Email: robin.hayeems@sickkids.ca<mailto:robin.hayeems@sickkids.ca 


\section{Short title:}

Parent experience with false positive CF screening

\section{Abbreviations in alphabetical order:}

Brief symptom inventory (BSI), child vulnerability scale (CVS), cystic fibrosis (CF), false positive (FP), maternal worry scale (MWS), maternal worry scale revised (MWS_r), newborn screening (NBS), parent perceived uncertainty scale (PPUS), response rate (RR), state trait anxiety index (STAI), Time 1 (T1), Time 2 (T2)

Funding source. CIHR Operating Grant

Financial Disclosure Statement: None

Conflict of Interest Statement: None

Clinical Trial registry name and registration number: N/A

What's Known on This Subject: Evidence is mixed with respect to psychosocial response to false positive newborn screening results. The role of the newborn screening system in optimizing patient experience is not well characterized.

What This Study Adds: Persistent psychosocial harm in mothers with FP results was not identified using selected measures but immediate distress was reported. In managing immediate distress and fears related to screen positive results, mothers highly value well-coordinated, efficient and patient-centered screening systems. 


\section{Contributors' Statement Page}

RZ Hayeems assisted with study leadership, including study design and development of the data collection plan. RZH participated in the oversight of data extraction and analysis, drafted and critically reviewed the manuscript, and approved the final manuscript as submitted.

FA Miller conceived of and led the study. FAM participated in the oversight of data analysis, critically reviewed the manuscript, and approved the final manuscript as submitted.

C Barg, Y Bombard, E Kerr, K Tam, JC Carroll, BK Potter assisted with study design and the development of the data collection plan, participated in the oversight of data extraction and analysis, critically reviewed the manuscript, and approved the final manuscript as submitted.

S Patton, J Bytautas, L Taylor, K Keenan, C Davies, J Milburn, A Price assisted with the development of the data collection plan, critically reviewed the manuscript, and approved the final manuscript as submitted.

P Chakraborty, T Gonska, F Ratjen assisted with study design, critically reviewed the manuscript, and approved the final manuscript as submitted.

A Guttmann conceived of and led the study. A Guttmann participated in the oversight of data analysis, critically reviewed the manuscript, and approved the final manuscript as submitted. 


\begin{abstract}
:
Background: The risk of psychosocial harm in families of infants with false positive (FP) newborn screening (NBS) results for cystic fibrosis (CF) is a longstanding concern. Whether well designed infant retrieval and confirmatory testing systems can mitigate risks remains unknown.
\end{abstract}

Methods: Using a mixed-methods cohort design, we obtained prospective self-report data from mothers of infants with FP CF NBS results 2-3 months after confirmatory testing at Ontario's largest follow-up centre, and from a randomly selected control sample of mothers of screen negative infants from the same region. Mothers completed a questionnaire assessing experience and psychosocial response. A sample of mothers of FP infants completed qualitative interviews.

Results: 134 mothers of FP infants (Response Rate 55\%) and 411 controls (Response Rate 47\%) completed questionnaires; 54 mothers of FP infants were interviewed. Selected psychosocial response measures did not detect psychosocial distress in newborns or one year later $(\mathrm{p}>0.05)$. Mothers recalled distress during notification of the positive result and in the follow-up testing period related to fear of chronic illness, but valued the screening system of care in mitigating concerns.

Conclusions: While immediate distress was reported among mothers of FP infants, selected psychometric tools did not detect these concerns. The NBS centre from which mothers were recruited minimizes delay between notification and confirmatory testing and ensures trained professionals are communicating results and facilitating follow-up. These factors may explain the presence of minimal psychosocial burden. The screening system reflected herein may be a model for NBS programs working to minimize FP-related psychosocial harm. 


\section{Introduction}

Newborn bloodspot screening (NBS) for cystic fibrosis (CF) is now established in many developed countries, ${ }^{1-4}$ as early detection improves nutritional status, height and weight gain. ${ }^{5}$ $\mathrm{CF}$ is the largest single disease contributor to screen positive NBS results in many jurisdictions, and is an exemplar case for understanding the impact of expanded NBS. Approximately $30 \%$ of screen positive cases/year identified in Ontario are attributable to $\mathrm{CF},{ }^{6}$ the majority of which are false positive (FP) upon confirmatory testing; as many as $80 \%$ of these are CF carriers. ${ }^{6,7}$

As part of efforts to balance benefits and burdens of population screening, the impact of FP results has long garnered attention. In the context of NBS, the concern dates back to 1968 when "PKU-Anxiety Syndrome" described the distressing experience of receiving FP results for phenylketonuria (PKU). ${ }^{8}$ Evidence has since accumulated suggesting that parents may experience a range of reactions related to receiving positive CF NBS results. Tluczek et al ${ }^{9}$ found that prior to confirmatory CF sweat testing, up to $43 \%$ of parents who had received an abnormal screening result experienced clinically significant depressive symptoms. However, after the sweat test, parents whose infants were found to be CF carriers did not differ from screen negative controls. Parents' prior knowledge of NBS, CF, and their own carrier status as well as the clinician's approach to informing them influenced this emotional reaction. ${ }^{9}$ Similarly, others have found that majorities of parents (74-96\%) reported high anxiety in reaction to positive NBS results but upon receiving normal sweat test results, majorities (64$86 \%$ ) were relieved. ${ }^{10,11}$ While detected anxiety appears to be transient, ${ }^{9-11}$ one to six years after identification, up to $29 \%$ of parents report worry about the health of their carrier child as well as potential difficulties posed for future relationships. Stress scores are also higher at one year 
post-disclosure among parents who received CF carrier versus negative results.${ }^{12-13}$ Parsons et

al, ${ }^{14}$ however, found that by 6 months post-disclosure, there was no evidence that carrier identification was associated with a compromised mother-baby relationship. Other survey and qualitative data suggest that, ultimately, the majority of parents feel better knowing their child's CF carrier status. ${ }^{9,15}$

While the negative psychosocial impact of FP results appears to be transient, vulnerability remains a concern. Responding to this evidence and as a broader measure of quality, Newborn Screening Ontario developed programmatic recommendations to minimize delay to confirmatory testing, ensure trained health professionals are communicating results to parents, and build partnerships with primary care providers. Presented herein are quantitative and qualitative data that reflect upon maternal lived experiences soon after CF NBS FP result notification in the context of a centralized provincial program.

\section{Participants and Methods}

In Ontario, CF NBS involves a two-step process of measuring immunoreactive trypsinogen (IRT) followed by screening the CF transmembrane regulator gene for 39 mutations. ${ }^{6}$ Infants with identified to have one CF mutation or an IRT $>$ 99th centile are referred for diagnostic sweat chloride testing. In collaboration with the CF clinic at the Hospital for Sick Children (SickKids) in Toronto (largest pediatric tertiary care centre in Canada), we conducted selfadministered postal surveys of mothers of CF screen positive infants and a control sample, at 2 months following the infant's birth (T1) and one year later (T2). We also conducted semistructured interviews with a sub-sample of FP survey respondents at both time-points. While 
the complete screen positive population included true-, false-, and inconclusive- positive infants, we focus herein on the longitudinal results from the T1 FP responder group. Research Ethics Boards at SickKids, The Children's Hospital of Eastern Ontario, and The University of Toronto approved this work.

\section{Sample and Recruitment}

T1 recruitment of mothers was prospective over 18 months. The full population of mothers of CF screen positive infants seen at SickKids, aged 4-6 weeks (i.e. confirmatory testing complete), were eligible to participate. Those facing extenuating perinatal circumstances, those undergoing adoption proceedings, mothers of multiples, and mothers facing a significant language barrier were excluded. The control sample (3:1 control:case ratio) included a random sample of mothers of infants in the population who screened negative for all disorders included in Ontario's NBS panel, resided within the SickKids catchment area (i.e. according to postal code boundaries), and were 4-6 weeks old. Mothers of infants with an unsatisfactory bloodspot were excluded as were mothers of infants facing adoption proceedings, blood transfusion, prematurity (i.e. gestational age $<36$ weeks), early death, or $>60$ day delay between date of birth and date of bloodspot collection.

Mothers of FP infants were notified of the study verbally and with a letter of introduction at the conclusion of their confirmatory sweat-testing appointment (4-6 weeks post-birth). Four weeks following this notification, potential participants who had not opted out were mailed a survey package. One follow-up package was sent one month later. For screen negative controls, mothers were notified of the study by mail, 4 weeks following birth. Potential controls who had 
not opted out were mailed a survey package and invited to participate, with three additional contacts (at 2-week intervals) for non-responders (i.e. modified Dillman method). ${ }^{15}$ In response to a poorer than expected response rate at three months (presumed attributable to the young age of the baby at initial contact), the recruitment timelines were slightly extended (Box 1). The overall shorter recruitment timeline for FP cases compared to controls reflects the differential burden appropriate to clinical and non-clinical study populations. ${ }^{16,17}$ Completion of the questionnaire constituted consent to participate. At T2, one year following the completion or administration of the T1 survey, T1 responders and non-responders were mailed a slightly modified second survey. The recruitment and survey administration process was the same as that used at T1 with FP notification mail.

\section{Data Collection and Analysis: Survey}

The survey package included (i) a team-developed, self-administered questionnaire gauging CF knowledge, understanding of screening result, experiences with the notification process, (ii) 5 self-administered measures of psychosocial response, (iii) demographic questions, and (iv) a study information sheet, a consent to re-contact form for the qualitative interview, and a small financial incentive ( $\$ 2$ coffee coupon). The questionnaire was adapted from existing instruments developed for NBS and CF research ${ }^{9-15,21-22,28-48}$ and pilot tested with new parents recruited from the Greater Toronto Area $(\mathrm{N}=15)$ through an online mothers' group. The core of the questionnaire was consistent across FP and control groups; non-applicable FP related content was removed from the control group questionnaire. The measures of psychological response included: (i) the State Subscale of the State Trait Anxiety Inventory (STAI) as a measure of anxiety, ${ }^{28-32}$ (ii) the Brief Symptom Inventory (BSI) as a measure of distress, ${ }^{33-39}$ 
(iii) the Child Vulnerability Scale (CVS) as a measure of maternal perception of infant vulnerability, ${ }^{40-43}$ (iv) a modified version of the Parental Perceptions of Uncertainty in Illness Scale (PPUS) as a measure of perceived uncertainty related to childhood illness, ${ }^{44-47}$ and (v) a modified version of the Maternal Worry Scale (MWS) as a measure of maternal worry ${ }^{48}(\underline{B o x}$ 2).

Questionnaire data were manually entered into IBM SPSS Statistics version 18. Where the data entry error rate was $>0.50 \%$, full double data entry was performed. We report cross-sectional analyses for $\mathrm{T} 1$ and repeated measures analyses for the subsample of respondents who completed both $\mathrm{T} 1$ and $\mathrm{T} 2$ questionnaires. We quantified the overall pattern of responses, reporting proportions with $95 \%$ CIs for discrete variables and means with standard deviations for continuous variables, for each of the FP and screen negative groups. T-tests were performed on log-transformed STAI, CVS, and PPUS scale data and on BSI t-scores. Since MWS scores were highly skewed and did not respond favorably to power transformation, non-parametric tests were used to gauge group differences. For T1 data, linear regression was performed to examine the association of FP status with anxiety, distress, vulnerability, and uncertainty, controlling for maternal characteristics where there was a difference between groups. Given multiple comparisons in the regression models, a more stringent $p$ value $(p<0.01)$ was used to determine statistical significance. We then performed two-factor mixed ANOVAs to gauge the effect of time on anxiety, distress, vulnerability, and uncertainty. Maternal worry was analyzed separately because data were concentrated at a score of 10 . We subtracted 10 from each score and treated the data as count data in order to compare screen negative and FP groups at each time point. Negative binomial regression was used for the subsample for whom we had T1 and 
$\mathrm{T} 2$ worry data (total $\mathrm{n}=255$ ), adjusting for the same confounders as the $\mathrm{T} 1$ linear regressions. At $\mathrm{T} 2$, a repeated measures negative binomial regression was performed on worry data.

\section{Data Collection and Analysis: Interviews}

Following our receipt of completed questionnaires, we conducted semi-structured, open-ended interviews with all mothers of FP infants who agreed (by checking a box on the questionnaire). Interviews were conducted by telephone where face-to-face was not preferred, or because of excess cost of travel to a distant location. The interview guide queried mothers' experiences receiving results, and their understanding of screen positive and confirmatory sweat testing results. Interviews were taped, transcribed and coded. We used a thematic approach, applying and modifying pre-existing codes from the interview guide pertaining to the experience of receiving FP results, and allowed new themes to emerge from the data using constant comparison. Through an iterative process, codes were refined and inconsistencies were resolved through discussion. ${ }^{49,50}$ We used $\mathrm{T} 1$ interviews to identify themes and then searched for confirming/disconfirming evidence and persistence of experience in $\mathrm{T} 2$ interviews.

\section{Results}

\section{Quantitative findings}

\section{Characteristics of survey respondents}

Of 246 eligible mothers of infants who received FP NBS results, 134 responded $(\mathrm{RR}=54.5 \%)$ to the survey, and of 869 eligible mothers of screen negative infants, 410 responded ( $R R=47.2 \%)$. Among mothers of FP infants, we report on 134 mothers (T1) of whom 82 (T2) completed T1 and T2 surveys. According to mothers, 141 (65.2\%) of these infants were confirmed to be 
carriers, 44 (20.4\%) were confirmed non-carriers, and for 31 (14.4\%), carrier status was

unknown. Among screen negative infants, we report on 410 mothers (T1) of whom 179 (T2) completed T1 and T2 surveys.

The characteristics of our survey samples are reported in Table 1. At T1, compared to controls, a greater proportion of mothers of FP infants reported living in rural areas $(p<0.05)$, fewer had completed undergraduate (or higher) degrees $(\mathrm{p}=0.02)$ and more reported that the index infant was their first child $(\mathrm{p}=0.01)$. Compared to an Ontario-based $\mathrm{CF}$ population, our participants were similar in education and income levels. ${ }^{51}$

\section{$\underline{\text { Psychosocial outcomes }}$}

In both the FP and control groups at $\mathrm{T} 1$ and $\mathrm{T} 2$, mean anxiety, distress, and vulnerability scores were low relative to reference means or clinical cut-offs where these were available from the literature (Box 2, Table 2), and not significantly different between groups (Table 2). While uncertainty scores were significantly different between groups at $\mathrm{T} 1$, the control group reported more uncertainty than the cases $(\mathrm{p}=0.03$; Table 2). Results of linear regression showed that FP status did not predict anxiety, distress, vulnerability or uncertainty at T1, controlling for relevant maternal characteristics ( $\underline{\text { Table } 3})$. Repeated measures analyses indicated no change in psychosocial response over time, except that uncertainty scores remained higher among controls at $\mathrm{T} 2(\mathrm{p}=0.03$; data not shown).

Maternal worry scores were significantly higher among mothers of FP infants compared to controls at T1 and T2 $(\mathrm{p}=0.002, \mathrm{p}=0.004$; Table 2$)$. When the worry scale item related to carrier children having a harder time making reproductive choices was removed (worry_revised), the 
significance of this effect disappeared. Adjusting for maternal characteristics, the negative binomial regression at T1 (using the 10-item worry scale) showed that FP status did not predict worry. Over time, worry decreased ( $\mathrm{p}=0.01$ ), and there was no difference between FP and controls on $\mathrm{T} 2$ worry scores (data not shown).

\section{Self-reported experiences}

With respect to the notification system itself, $61 \%$ of mothers in the FP group were notified of their results from their primary care provider and 39\% were notified by a genetic counselor. Only $13 \%$ indicated that they would have preferred to receive this notification from someone else; of those $47 \%$ indicated a preference for their primary care provider and 53\% indicated a preference for a counselor from the screening program. Finally, when prompted by a survey question, $87 \%$ of mothers agreed that the time between being notified about the positive screen and learning the final results "was the scariest time of my life." At the time of the second survey, only $14 \%$ agreed with this fear.

\section{Qualitative findings}

\section{Characteristics of interview participants}

31 mothers who received FP results for their infants were interviewed at T1 and 35 mothers were interviewed one year later, at T2. Of those interviewed at T2, 23 were new participants and 12 were interviewed at $\mathrm{T} 1$ and comprise a longitudinal sub-sample.

\section{The lived experience}


From $31 \mathrm{~T} 1$ qualitative interviews, we identified two major themes. The first relates to the nature of the distress that was experienced. From mothers' perspectives, receiving the notification phone call was frightening. Having been home from hospital with an apparently healthy baby and having perceived their discharge and non-involvement with the health care system as a "clean bill of health," it was alarming to learn that their child might have a chronic illness. Mothers reasoned that receiving this news on the heels of their own post-partum recovery likely added to the intensity of their response. Following receipt of this unexpected information, mothers attributed unusual newborn behavior (e.g. congestion, spit up, raspy breathing) to a possible diagnosis of $\mathrm{CF}$, described a process of symptom seeking (e.g. licking the baby to gauge "saltiness"), and a fear of living a life with a child with a chronic illness (Table 4). Among 23 new participants interviewed at T2, most reported similar distress in retrospect, but few reported ongoing distress. Of the 12 longitudinal participants, 3 reported a persistence of the distress that was reported at $\mathrm{T} 1$.

The second major theme relates to how the screening and tertiary care systems - and various players within this coordinated system - were valued by mothers and worked to mitigate the distress that was experienced. Mothers placed tremendous value on the fact that time to confirmatory testing was quick (generally $\leq 48$ hours). They valued the active coordination of their care; specifically, being given a time and location to attend for confirmatory testing. While mothers had mixed views about the importance of pre-test NBS education, mothers valued what they experienced as clear, calm, and sensitive communication from the involved heath care providers at both notification and confirmatory points in time ( $\underline{\text { Table } 4})$. 


\section{Discussion}

Using mixed methods, we provide a unique contribution to unresolved questions of psychosocial response to FP NBS results. A first key finding is that measures of psychosocial harm related to anxiety, distress, vulnerability and uncertainty were not increased in mothers of infants with FP results in the early newborn period or one year later. While no signal of harm was detected on these psychometric tools, a majority of mothers agreed that the FP experience had been the "scariest time in their lives" and reported worry about future family planning for their carrier infants. Similarly, in interviews, mothers of infants with FP results recalled distress during the notification and diagnostic follow-up periods, stemming from the unexpected nature of the information, symptom-seeking, and a fear of chronic disease. For most, distress did not persist one year later.

Our second key finding relates to the NBS system itself. Given longstanding concern about the risk of psychosocial harm in families of infants with FP results, NBS programs seek to mitigate potential distress. ${ }^{52-58}$ Specifically, Ontario has developed a notification system that aims to minimize delay to confirmatory testing, provides point of care fact sheets to health professionals who are communicating results to parents and responding to questions, and aims to achieve a partnership with primary care providers who often play an initial notification role. Our qualitative data indicate that parents valued this carefully structured screening system and perceive its role in mitigating FP-related distress. More specifically, parents valued the short waiting period preceding confirmatory testing. While measurable psychosocial distress has been identified among parents of screen positive infants, this may be associated with the longer waiting periods for confirmatory testing that were experienced in earlier years of CF NBS.,59-61 
The absence of such distress on similar tools used herein underscores the importance of short waiting periods (i.e. $<48$ hours) for optimal patient experience. Additionally, mothers were content to defer to the screening system for logistics pertaining to follow-up and reflected favorably on provider communication and education strategies, whether offered by primary care providers or NBS program-affiliated genetic counselors.

We acknowledge several limitations. Since our study attracted a well-educated cohort of mothers that may have been better equipped to understand this experience, our findings may not be generalizable to mothers with less education. Others have reported an important link between knowledge/understanding of NBS results and psychosocial response ${ }^{9,15}$ so our findings must be considered in this light. Moreover, mothers of FP infants who are confirmed to be carriers may respond favorably to the receipt of this reproductive risk information. ${ }^{10}$ The majority of our cohort represents the experience of mothers of carrier infants, possibly limiting the generalizability of these results to mothers of FP non-carriers. Second, our qualitative interviews were designed as two cross-sectional interviews, so did not actively probe change over time. Finally, the results may not be applicable to other disease screen positive populations.

Limitations notwithstanding, our mixed methods approach enables an enhanced understanding of maternal response to FP NBS results. While our findings from selected psychometric tools align with previous studies that report minimal adverse psychosocial sequelae, ${ }^{9-11}$ other survey and qualitative findings suggest that parents experience distress and depend on the support provided by a well-structured screening system. Parental reflections on the role of the screening 
system in mitigating potential distress are novel and confirm the need for investment in

centralized, well-coordinated, efficient screening systems in all jurisdictions to optimize patient experiences and outcomes.

Acknowledgement: We thank Dr. Rahim Moineddin for his support with statistical analyses. 


\section{References}

1. Pollitt RJ. International perspectives on newborn screening. J Inherit Metab Dis. 2006 Apr-Jun;29(2-3):390-6.

2. Watson M, Mann M, Lloyd-Puryear M, et al. Newborn Screening: Towrad a Uniform Screenign Panel and System--Executive Summary. Pediatrics 2006;117(5):S296-S307.

3. Newborn Screening In Canada Status Report Nov 2013. Canadian Organization for Rare Disorders. Available at: https://www.raredisorders.ca/documents/CanadaNBSstatusupdatedNov.82013.pdf Accessed on: August 42015.

4. European Cysric Fibrosis Society; Neonatal Screening Work Group Newsletter, July 2015. Available at:https://www.ecfs.eu/sites/default/files/documents/NSWG_newsletter_annual_meeting _report2015.pdf Accesed on: August 4, 2015.

5. Southern K, Mérelle M, Dankert-Roelse J, et al. Newborn screening for cystic fibrosis (Review). Cochrane Database of Systematic Reviews 2008;4(CD001402).

6. Newborn Screening Ontario Annual Report 2012. Available at: http://www.newbornscreening.on.ca/data/1/rec_docs/700_2012_NSO_Annual_Public Report.pdf Accessed on: August 4, 2015.

7. Comeau AM, Accurso FJ, White TB, et al. Guidelines for implementation of cystic fibrosis newborn screening programs: Cystic fibrosis foundation workshop report. Pediatrics 2007;119(2):e495-518.

8. Rothenberg MB and Sills EM. Iatrogenesis: the PKU anxiety syndrome.J Am Acad Child Psychiatry. 1968 Oct;7(4):689-92.

9. Tluczek A, Koscik RL, Farrell PM, et al. Psychosocial risk associated with newborn screening for cystic fibrosis: parents' experience while awaiting the sweat-test appointment. Pediatrics 2005;115(6):1692 - 703.

10. Lewis S, Curnow L, Ross M, et al. Parental attitudes to the identification of their infants as carriers of cystic fibrosis by newborn screening. Jounral of Paediatrics and Child Health 2006;42(9):533-7.

11. Beucher J1, Leray E, Deneuville E, et al. Psychological effects of false-positive results in cystic fibrosis newborn screening: a two-year follow-up. J Pediatr. 2010 May;156(5):771-6, 776.e1. doi: 10.1016/j.jpeds.2009.12.003. Epub 2010 Feb 20.

12. Baroni MA, Anderson YE, Mischler E. Cystic fibrosis newborn screening: impact of early screening results on parenting stress. Pediatric Nursing 1997;23(2):143-51.

13. Mischler EH, Wilfond BS, Fost N, et al. Cystic fibrosis newborn ncreening: Impact on reproductive behaviour and implications for genetic counseling. Pediatrics 1998;102(1):44-52.

14. Parsons EP, Clarke AJ, Bradley DM. Implications of carrier identification in newborn screening for cystic fibrosis, 2003:F467-71.

15. Ciske DJ, Haavisto A, Laxova A, et al. Genetic counseling and neonatal screening for cystic fibrosis: An assessment of the communication process. Pediatrics 2001;107(4):669-705.

16. Dillman D, Smyth J, Christian L. Internet, Mail, and Mixed-Mode Surveys: The Tailored Design Method. 3rd ed. Hoboken, New Jersey: John Wiley \& Sons, Inc., 2009.

17. Miron I, Tam K, Miller F, et al. Sick Kids REB Application, MSc Research. Toronto, 2009. 
18. Araia M, Potter B, Chakraborty P, al. e. CHEO REB Application, MSc thesis research. Ottawa, 2009.

19. Marteau TM, van Duijn M, Ellis I. Effects of genetic screening on perceptions of health: A pilot study. Journal of Medical Genetics 1992;29(1):24-6.

20. Moran J, Quirk K, Duff AJA, et al. Newborn screening for CF in a regional paediatric centre: The psychosocial effects of false-positive IRT results on parents. Journal of Cystic Fibrosis 2007;6(3):250-4.

21. Hewlett J, Waisbren SE. A review of the psychosocial effects of false-positive results on parents and current communication practices in newborn screening. Journal of Inherited Metabolic Disorders 2006;29(5):677-82.

22. Waisbren SE, Albers S, Amato S, et al. Effect of expanded newborn screening for biochemical genetic disorders on child outcomes and parental stress. JAMA 2003;290(19):2564 - 72.

23. Miller FA, Paynter M, Hayeems R, et al. Understanding sickle cell carrier status identified through newborn screening: A qualitative study. European Journal of Human Genetics 2010;18:303-8.

24. Ulph F, Cullinan T, Qureshi N, et al. Informing children of their newborn screening carrier result for sickle cell or cystic fibrosis: qualitative study of parents' intentions, views and support needs. J Genet Counsel 2014 23:409-420

25. Kemper AR, Uren RL, Moseley KL, et al. Primary care physicians' attitudes regarding follow-up care for children with positive newborn screening results. Pediatrics 2006;118(5):1836-41.

26. Farrell M, Certain L, Farrell P. Genetic counseling and risk communication services of newborn screening programs. Archives of Pediatrics and Adolescent Medicine 2001;155(2):120-6.

27. Miller FA, Hayeems R, Paynter M, et al. Carrier status determined as a result of newborn screening for sickle cell disorders: exploration of alternatives for management of carrier status information in Ontario: Ministry of Health and Long-Term Care, 2007:34.

28. Spielberger C, Gorsuch R, Lushene R, et al. State-Trait Anxiety Inventory. Consulting Psychologists Press, Inc. 1983.

29. Bennett Johnson S, Baughcum A, Carmichael S, et al. Maternal anxiety associated with newborn genetic screening for type 1 diabetes. Diabetes Care 2004;27(2):392-7.

30. van der Ploeg C, Lanting C, Kauffman-de Boer M, et al. Examination of long-lasting parental concern after false-positive results of neonatal hearing screening. Archives of Disease in Childhood 2008;93(6):508-11.

31. Parsons E, Clarke A, Hood K, et al. Newborn screening for Duchenne muscular dystrophy: a psychosocial study. Archives of disease in childhood. Fetal and neonatal edition 2002;86:F91-5.

32. Gordon C, Walpole I, Zubrick SR, et al. Population screening for cystic fibrosis: Knowledge and emotional consequences 18 months later. American journal of medical genetics Part A 2003;120A(2):199-208.

33. Derogatis L. BSI Brief Symptom Inventory: Administration, Scoring, and Procedures Manual. 4th ed. Minneapolis, Minnesota: National Computer Systems, 1993. 
34. Brosig C, Whitstone B, Frommelt M, et al. Psychological distress in parents of children with severe congenital heart disease: the impact of prenatal versus postnatal diagnosis. Journal of Perinatology 2007;27:687-92.

35. Wiegner S, Donders J. Predictors of parental distress after congenital disabilities. Journal of Developmental and Behavioral Pediatrics 2000;21(4):271-7.

36. Singer L, Fulton S, Davillier M, et al. Effects of Infant Risk Status and Maternal Psychological Distress on Maternal-Infant Interactions During the First Year of Life. Developmental and Behavioral Pediatrics 2003;24(4):233-41.

37. Bielinski-Blattmann D, Lemola S, Jaussi C, et al. Postpartum depressive symptoms in the first 17 months after childbirth: the impact of an emptionally supportive partnership. International Journal of Public Health 2009;54(5):333-9.

38. Anderson L, Campbell M, daSilva O, et al. Effect of maternal depression and anxiety on use of health services for infants. Canadian Family Physician 2008;54(12):1718-19.

39. Kerruish N, Campbell-Stokes P, Gray A, et al. Maternal psychological reaction to newborn genetic screening for type 1 diabetes. Pediatrics 2007;120:e324-e35.

40. Forsyth B, McCue Horowitz S, Leventhal J, et al. The Child Vulnerability Scale: An Instrument to Measure Parental Perceptions of Child Vulnerability. Journal of Pediatric Psycology 1996;21(1):89-101.

41. Kerruish N, Settle K, Campbell-Stokes P, et al. Vulnerable baby scale: development and piloting of a questionnaire to measure maternal perceptions of their baby's vulnerability. Journal of Paediatrics and Child Health 2005;41:419-23.

42. Dogan DG1, Ertem IO, Karaaslan T, et al. Perception of vulnerability among mothers of healthy infants in a middle-income country. Child Care Health Dev. 2009 Nov;35(6):868-72.

43. Tluczek A1, McKechnie AC, Brown RL. Factors associated with parental perception of child vulnerability 12 months after abnormal newborn screening results. Res Nurs Health. 2011 Oct;34(5):389-400.

44. Mishel MH. Parents' perception of uncertainty concerning their hospitalized child. Nurs Res. 1983;32:324-330.

45. Santacroce SJ. Measuring parental uncertainty during the diagnosis phase of serious illness in a child. J Pediatr Nurs. $2001 \mathrm{Feb} ; 16(1): 3-12$.

46. Lenhard W, Breitenbach E, Ebert H, et al. Psychological benefit of diagnostic certainty for mothers of children with disabilities: Lessons from Down syndrome. Am. J. Med. Genet. A. 2005; 133A:170-175.

47. Madeo AC, O'Brien KE, Bernhardt BA, et al. Factors Associated with Perceived Uncertainty among Parents of Children with Undiagnosed Medical Conditions. Am J Med Genet A. 2012 August ; 158A(8): 1877-1884. doi:10.1002/ajmg.a.35425.

48. DeVet KA1, Ireys HT. Psychometric properties of the maternal worry scale for children with chronic illness. J Pediatr Psychol. 1998 Aug;23(4):257-66.

49. Patton M. Qualitative Research and Evaluation Methods. Third ed. Thousand Oaks: Sage Publications, 2002.

50. Sandelowski M. Whatever happened to qualitative description? Research in Nursing and Health 2000;23:334-40.

51. Cohen E, Gandhi S, Toulany A, et al. Health Care Use During Transfer to Adult Care Among Youth With Chronic Conditions. Pediatrics. 2016;137(3):e20152734 
52. Ciske DJ, Haavisto A, Laxova A, et al. Genetic counseling and neonatal screening for cystic fibrosis: An assessment of the communication process. Pediatrics 2001;107(4):669-705.

53. Oliver S, Dezateux C, Kavanagh J, et al. Disclosing to parents newborn carrier status identified by routine blood spot screening. In: Unit SSR, editor. London: University of London, 2004:1-61.

54. Comeau AM, Accurso FJ, White TB, et al. Guidelines for implementation of cystic fibrosis newborn screening programs: Cystic fibrosis foundation workshop report. Pediatrics 2007;119(2):e495-518.

55. Wheeler P, Smith R, Dorkin H, et al. Genetic counseling after implementation of statewide cystic fibrosis newborn screening: Two years' experience in one medical centre. Genetics in Medicine 2001;3(6):411-15.

56. Kim S, Lloyd-Puryear MA, Tonniges TF. Examination of the communication practices between state newborn screening programs and the medical home. Pediatrics 2003;111(2):E120-6.

57. Kemper AR, Uren RL, Moseley KL, et al. Primary care physicians' attitudes regarding follow-up care for children with positive newborn screening results. Pediatrics 2006;118(5):1836-41.

58. Thompson D, Ahrens M, LeRoy B, et al. Newborn blood spot screening and genetic services: a survey of Minnesota primary care physicians. Genetics in Medicine 2005;7(8):6.

59. Helton JL, Harmon RJ, Robinson N, Accurso FJ. Parental attitudes toward newborn screening for cystic fibrosis. Pediatr Pulmonol Suppl 1991;7:23-8.

60. Moran J, Quirk K, Duff AJ, Brownlee KG. Newborn screening for CF in a regional paediatric centre: the psychosocial effects of false-positive IRT results on parents. J Cyst Fibros 2007;6:250-4.

61. Hayeems RZ, Bytautas JP, Miller FA. A systematic review of the effects ofcdisclosing carrier results generated through newborn screening. J Genet Counsel 2008;17:538-49. 
Box 1: Time 1 Recruitment

\begin{tabular}{|l|c|c|c|c|c|c|c|c|}
\hline Wks post birth & $4-6$ & $\mathbf{6 - 8}$ & $\mathbf{8 - 1 0}$ & $\mathbf{1 0 - 1 2}$ & $\mathbf{1 2 - 1 4}$ & $\mathbf{1 4 - 1 6}$ & $\mathbf{1 4 - 1 6}$ & $\mathbf{1 6 - 1 8}$ \\
\hline Cases & $\mathrm{X}$ & & $\mathrm{X}$ & $\mathrm{X}$ & $\mathrm{X}$ & $\mathrm{X}$ & & \\
\hline Controls & $\mathrm{X}$ & $\mathrm{X}$ & $\mathrm{X}$ & $\mathrm{X}$ & $\mathrm{X}$ & $\mathrm{X}$ & $\mathrm{X}$ & $\mathrm{X}$ \\
\hline
\end{tabular}

$\mathrm{X}$ : original recruitment schedule $\mathrm{X}$ : extended recruitment schedule

Box 2: Psychosocial Response Tools

\begin{tabular}{|c|c|c|c|}
\hline Scale & Item Format & Psychometric Properties & Domains of use \\
\hline $\begin{array}{l}\text { STAI }(20 \\
\text { item })^{28}\end{array}$ & $\begin{array}{l}\text { 4-point scale from 'not at } \\
\text { all' to 'very much so' }\end{array}$ & $\begin{array}{l}\text { Scores range from } 20-80 \text {; mean (working } \\
\text { women) is } 34.79(\mathrm{SD}=9.22) \text {; mean }(14 \mathrm{w} \\
\text { postpartum women) } 30.43 \text {; good construct } \\
\text { validity, discriminating adults with } \\
\text { generalized anxiety disorder }{ }^{28}\end{array}$ & $\begin{array}{l}\text { Used in NBS research to } \\
\text { measure anxiety }{ }^{14,29-32}\end{array}$ \\
\hline 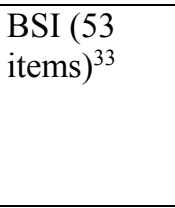 & $\begin{array}{l}\text { 5-point scale from 'not at } \\
\text { all' to 'extremely' }\end{array}$ & $\begin{array}{l}\text { Internal consistency, test-retest reliability } \\
\text { and validity demonstrated }{ }^{33}\end{array}$ & $\begin{array}{l}\text { Used to assess impact of } \\
\text { newborn diagnosis and as } \\
\text { a measure of adjustment } \\
\text { over time. }{ }^{34-39} \text { Has not } \\
\text { been used in NBS research }\end{array}$ \\
\hline $\begin{array}{l}\text { CVS }(8- \\
\text { items })^{40}\end{array}$ & $\begin{array}{l}\text { 4-point scale from } \\
\text { 'strongly disagree' to } \\
\text { 'strongly agree' }\end{array}$ & $\begin{array}{l}\text { Total scores range from } 0-24 \text {. In a clinical } \\
\text { population, scores } \geq 10 \text { indicate elevated } \\
\text { perceptions of vulnerability; Internal } \\
\text { consistency, test-retest reliability and } \\
\text { validity are well demonstrated }{ }^{40}\end{array}$ & $\begin{array}{l}\text { Used in NBS research to } \\
\text { measure response to } \\
\text { positive NBS results }\end{array}$ \\
\hline $\begin{array}{l}\text { PPUS (4 } \\
\text { items) }\end{array}$ & $\begin{array}{l}\text { 5-point scale from } \\
\text { 'strongly agree' to } \\
\text { 'strongly disagree' }\end{array}$ & $\begin{array}{l}\text { Measures the uncertainty parents } \\
\text { experience related to their child's illness; } \\
\text { higher scores indicate greater perception of } \\
\text { uncertainty. Internal consistency, test- } \\
\text { retest reliability and validity } \\
\text { demonstrated }^{44} \text {; modified as per Table } 3\end{array}$ & $\begin{array}{l}\text { Used to gauge perceived } \\
\text { parental uncertainty } \\
\text { between identification of } \\
\text { symptoms in a child and } \\
\text { point of diagnosis. }{ }^{45-47} \text { Has } \\
\text { not been used in NBS } \\
\text { research }\end{array}$ \\
\hline $\begin{array}{l}\text { MWS (10- } \\
\text { item }^{48}\end{array}$ & $\begin{array}{l}\text { 4-point scale; worry' } \\
\text { most of the time', } \\
\text { 'often', 'sometimes', and } \\
\text { 'not at all' }\end{array}$ & $\begin{array}{l}\text { Internal consistency, test-retest reliability } \\
\text { and validity demonstrated }{ }^{48} \text {; modified as } \\
\text { per Table } 3\end{array}$ & $\begin{array}{l}\text { Used for mothers of } \\
\text { children with chronic } \\
\text { illness. }{ }^{48} \text { Hasnot been used } \\
\text { in NBS research }\end{array}$ \\
\hline
\end{tabular}


Table 1: Overall Sample Characteristics

\begin{tabular}{|c|c|c|c|c|c|c|}
\hline & \multicolumn{3}{|c|}{ Time 1} & \multicolumn{3}{|c|}{ Time 2} \\
\hline & $\begin{array}{c}\text { False } \\
\text { positive } \\
(n, \%)\end{array}$ & $\begin{array}{c}\text { Screen } \\
\text { negative } \\
(n, \%)\end{array}$ & $\begin{array}{c}X^{2} \\
p \text {-value }\end{array}$ & $\begin{array}{c}\text { False } \\
\text { positive }(n, \\
\%) \\
\end{array}$ & $\begin{array}{c}\text { Screen } \\
\text { negative }(n, \\
\%)\end{array}$ & $\begin{array}{c}X^{2} \\
p \text {-value }\end{array}$ \\
\hline Age & $n=134$ & $n=405$ & & $n=82$ & $n=179$ & \\
\hline 25 and under & $9(6.7 \%)$ & $26(6.4 \%)$ & \multirow[t]{4}{*}{0.54} & $3(3.7 \%)$ & $3(1.7 \%)$ & \multirow[t]{4}{*}{$0.73^{\wedge}$} \\
\hline $26-30$ & $28(20.9 \%)$ & $110(27.2 \%)$ & & $14(17.1 \%)$ & $36(20.1 \%)$ & \\
\hline $31-35$ & $59(44.0 \%)$ & $160(39.5 \%)$ & & $33(40.2 \%)$ & $72(40.2 \%)$ & \\
\hline $36+$ & $38(28.4 \%)$ & $109(26.9 \%)$ & & $32(39.0 \%)$ & $68(38.0 \%)$ & \\
\hline City of residence, population size & $n=133$ & $n=410$ & & $n=81$ & $n=179$ & \\
\hline $100,000+$ & $93(69.9 \%)$ & $330(80.5 \%)$ & \multirow[t]{2}{*}{$0.02 *$} & $54(66.7 \%)$ & $141(78.8 \%)$ & \multirow[t]{2}{*}{$0.045^{*}$} \\
\hline$<100,000$ & $40(30.1 \%)$ & $80(19.5 \%)$ & & $27(33.3 \%)$ & $38(21.2 \%)$ & \\
\hline First child $^{a}$ & $n=134$ & $n=315$ & & $n=82$ & $n=179$ & \\
\hline Yes & $72(53.7 \%)$ & $127(40.3 \%)$ & \multirow[t]{2}{*}{$0.01 *$} & $46(56.1 \%)$ & $82(45.8 \%)$ & \multirow[t]{2}{*}{0.14} \\
\hline No & $62(46.3 \%)$ & $188(59.7 \%)$ & & $36(43.9 \%)$ & $97(54.2 \%)$ & \\
\hline Marital status & $n=134$ & $n=410$ & & $n=82$ & $n=179$ & \\
\hline Married or common law & $123(91.8 \%)$ & $380(92.7 \%)$ & \multirow[t]{2}{*}{0.71} & $79(96.3 \%)$ & $166(92.7 \%)$ & \multirow[t]{2}{*}{0.29} \\
\hline Other & $11(8.2 \%)$ & $30(7.3 \%)$ & & $3(3.7 \%)$ & $13(7.3 \%)$ & \\
\hline Education, highest level completed & $n=134$ & $n=408$ & & $n=82$ & $n=179$ & \\
\hline High school or less & $18(13.4 \%)$ & $57(14.0 \%)$ & \multirow[t]{4}{*}{$0.02 *$} & $9(11.0 \%)$ & $23(12.8 \%)$ & \multirow[t]{4}{*}{0.25} \\
\hline College or CEGEP & $54(40.3 \%)$ & $107(26.2 \%)$ & & $29(35.4 \%)$ & $42(23.5 \%)$ & \\
\hline Undergrad & $27(20.1 \%)$ & $112(27.5 \%)$ & & $20(24.4 \%)$ & $55(30.7 \%)$ & \\
\hline Grad or professional & $35(26.1 \%)$ & $132(32.4 \%)$ & & $24(29.3 \%)$ & $59(33.0 \%)$ & \\
\hline Annual household income & $n=129$ & $n=398$ & & $n=78$ & $n=163$ & \\
\hline Under $\$ 80,000$ & $52(40.3 \%)$ & $180(45.2 \%)$ & \multirow[t]{2}{*}{0.36} & $22(28.2 \%)$ & $58(35.6 \%)$ & \multirow[t]{2}{*}{0.26} \\
\hline$\$ 80,000+$ & $77(59.7 \%)$ & $218(54.8 \%)$ & & $56(71.8 \%)$ & $105(64.4 \%)$ & \\
\hline
\end{tabular}

$p$-value $<0.05 \wedge$ Fisher's Exact 
Table 2: T1 cross sectional \& T2 longitudinal maternal psychosocial response

\begin{tabular}{|c|c|c|c|c|c|c|}
\hline & \multicolumn{3}{|c|}{ Time 1 } & \multicolumn{3}{|c|}{ Time $2^{\sim}$} \\
\hline & \multicolumn{2}{|c|}{ Mean scores (SD) } & \multicolumn{4}{|c|}{ Mean scores (SD) } \\
\hline & False positive & $\begin{array}{c}\text { Screen } \\
\text { negative }\end{array}$ & $t$-test $p$-value & False positive & $\begin{array}{c}\text { Screen } \\
\text { negative }\end{array}$ & $t$-test $p$-value \\
\hline Anxiety & $31.23(10.30)$ & $32.39(8.94)$ & 0.12 & $31.48(9.03)$ & $32.74(10.23)$ & 0.41 \\
\hline Distress $^{\wedge}$ & $55.35(9.90)$ & $56.03(10.67)$ & 0.52 & $53.85(10.46)$ & $53.79(11.21)$ & 0.97 \\
\hline Vulnerability & $4.79(3.49)$ & $5.53(4.16)$ & 0.26 & $4.59(3.60)$ & $5.23(3.68)$ & 0.22 \\
\hline Uncertainty $^{\wedge \wedge}$ & $8.04(2.41)$ & $8.61(2.64)$ & $0.03 *$ & $7.57(2.37)$ & $8.19(2.50)$ & 0.051 \\
\hline Worry $^{\wedge \wedge \wedge}$ & $10.81(2.51)$ & $10.71(2.27)$ & $.002 * *$ & $10.73(2.30)$ & $10.39(1.40)$ & $.004 * *$ \\
\hline Worry_revised & $9.49(2.42)$ & $9.66(2.08)$ & .314 & $9.46(2.27)$ & $9.36(1.26)$ & .41 \\
\hline \multicolumn{7}{|c|}{$\begin{array}{l}* p<.05 ; * * p<.019 ;: \text { t-tests performed on log transformed scale data, descriptive statistics reported on raw data; } \sim \text { T1 } \\
\text { participants completed survey when infants was } 2 \text { months of age; T2 survey completed } 1 \text { year later; } \wedge \text { BSI: } t \text { scores reported; } \\
\text { measured } 15 \text { items to gauge general distress, using the depression and obsessive behaviors sub-scales and } 14 \text { additional items to } \\
\text { generate Global Severity Index }{ }^{33,37-39 \wedge \wedge P P U S: ~ e l i m i n a t e d ~ i t e m s ~ r e l a t e d ~ t o ~ m e d i c a l ~ t r e a t m e n t, ~ a t t i t u d e s ~ t o w a r d ~ h e a l t h ~ c a r e ~} \\
\text { providers, and items not specifically about uncertainty in health and illness; revised items to be about babies and to be CF- } \\
\text { specific }{ }^{\wedge} \text { MWS: changed "health condition" to "health", removed } 4 \text { items specific to being sick/using medication, added } 3 \\
\text { items to suit context of genetics; Mann-Whitney U test performed due to the nonparametric nature of data; MWS means } \\
\text { reported for consistency with other measures; MWS_revised: 9-item version with the item re: worry about children’s choices } \\
\text { about having children removed. }\end{array}$} \\
\hline
\end{tabular}

Table 3. Psychosocial response regression results at Time 1

\begin{tabular}{|c|c|c|c|c|}
\hline & $\begin{array}{l}\text { Anxiety } \\
(B, S E)\end{array}$ & $\begin{array}{l}\text { Distress } \\
(B, \mathrm{SE})\end{array}$ & $\begin{array}{c}\text { Vulnerability } \\
\qquad(B, \mathrm{SE})\end{array}$ & $\begin{array}{c}\text { Uncertainty } \\
(B, \mathrm{SE})\end{array}$ \\
\hline FP (ref: control) & $-.013(.013)$ & $-.405(1.129)$ & $-.024(.036)$ & $-.033^{\mathrm{a}}(.014)$ \\
\hline $\begin{array}{l}\text { First child missing (ref: } \\
\text { no) }\end{array}$ & $.023(.015)$ & $.954(1.308)$ & $.005(.041)$ & $.013(.017)$ \\
\hline First child - yes (ref: no) & $-.012(.012)$ & $.093(1.026)$ & $-.035(.033)$ & $.023(.013)$ \\
\hline $\begin{array}{l}\text { City size }-100,000+(\text { ref: } \\
<100,000)\end{array}$ & $.000(.013)$ & $.435(1.129)$ & $.012(.036)$ & $-.010(.014)$ \\
\hline $\begin{array}{l}\text { Education: } \\
\text { college/CEGEP (ref: } \\
\text { grad/professional) }\end{array}$ & $.012(.014)$ & $1.213(1.194)$ & $-.053(.038)$ & $.009(.015)$ \\
\hline $\begin{array}{l}\text { Education: undergrad } \\
\text { (ref: grad/professional) }\end{array}$ & $-.003(.014)$ & $.611(1.215)$ & $-.073(.039)$ & $-.017(.016)$ \\
\hline Education: high school & $.012(.017)$ & $-1.071(1.504)$ & $-.067(.047)$ & $-.008(.019)$ \\
\hline
\end{tabular}


Table 4: Qualitative themes and illustrative statements

\begin{tabular}{|c|c|}
\hline Theme & Illustrative Statement \\
\hline \multicolumn{2}{|c|}{ Mothers experience distress in the early days } \\
\hline The news is distressing & $\begin{array}{l}\text { Just as you think everything is going so perfectly, you hear this... it is so scary; } \\
\text { you always think it happens to other people... (205) } \\
\text { I just shut down. I didn't hear anything. She kept talking and I could tell she was } \\
\text { trying to calm me down, but I couldn't hear anything she was saying. (015) } \\
\text { Well, I guess it kind of blew me out of the water...we signed the form in the } \\
\text { hospital... but didn't know anything really about it, so forgot about it. So, when } \\
\text { the call came it knocked me on my butt... (050) }\end{array}$ \\
\hline $\begin{array}{l}\text { The news triggers symptom } \\
\text { monitoring }\end{array}$ & $\begin{array}{l}\text { All I kept saying was 'she's got cystic fibrosis. That's why...' She was really } \\
\text { congested... I said, 'oh my god, this is why she's this. This is why this happened. } \\
\text { This is why she keeps throwing up when she eats.(015) } \\
\text { No, we just spent the two days looking up symptoms, trying to find reasons that } \\
\text { would explain... his behaviour because he was eating a lot... had raspy breath. } \\
\text { So, I thought, oh my god, those are symptoms. We licked him. And then, I } \\
\text { swaddled him up and made him sweat some and licked him more... (052) } \\
\text { But you worry... you start to think of every little cough... she tends to drink a lot } \\
\text { of milk, chugs it and then spurts it all up and, you know, is that her drowning in } \\
\text { mucus cause she can't drink it properly? Your brain just goes. (234) }\end{array}$ \\
\hline $\begin{array}{l}\text { The news leads to fearing a } \\
\text { life of chronic illness }\end{array}$ & $\begin{array}{l}\text { But you know, my husband was sitting there in the waiting room, nervous and, } \\
\text { and looking at all these other poor children that are there for different reasons, } \\
\text { you know, are really, really sick and, and you start to really think about, this } \\
\text { could be my reality (173) } \\
\text { As soon as I got there it was even more stressful because I was, like, 'oh my god, } \\
\text { I'm going to be coming here for the rest of my life.... it was really stressful... I } \\
\text { walked in there and I'm seeing other kids with, like... I don't know what you call } \\
\text { those long stick things with, like, the drippies on them. And, I'm, like, 'oh god, } \\
\text { I'm going to... that's going to be my kid' (017) } \\
\text { Really it was just fear, but it was fear for different people as well. Like, it wasn't } \\
\text { just a fear for her. It was a fear for my older son and if she suddenly had a } \\
\text { condition that required a lot of specialists and doctor's appointments, what did } \\
\text { that mean for him and our family? (141) }\end{array}$ \\
\hline \multicolumn{2}{|c|}{ The system response helps to mitigate the distress that is experienced } \\
\hline It was quick and prescribed & $\begin{array}{l}\text { Was great that we didn't have to wait because... waiting like } 2 \text { or } 3 \text { weeks for an } \\
\text { appointment... You would have just made yourself sick with worry...48 hours is } \\
\text { long enough... if you had to wait like } 2 \text { weeks, then you know, you really get } \\
\text { your anxiety level up... [173] } \\
\text { So I was thrilled with that approach......to have her just tell us, "show up at this }\end{array}$ \\
\hline
\end{tabular}




\begin{tabular}{|c|c|}
\hline & $\begin{array}{l}\text { time"... we didn't have to do anything. So that eliminated a whole other set of } \\
\text { questions in what do we do now and who do I call? And, we didn't have to do } \\
\text { any of that.(129) }\end{array}$ \\
\hline $\begin{array}{l}\text { Communication was effective } \\
\text { and sensitive from } \\
\text { notification to confirmation }\end{array}$ & $\begin{array}{l}\text { She had a really, really positive outlook. And, she was really calm. And, you } \\
\text { know, I don't... it wouldn't have made it any worse or better hearing it from my } \\
\text { family doctor or something, or somebody that I knew... You know, the way she } \\
\text { presented the information I think made a huge difference even though I didn't... } \\
\text { I've never spoken to her before. (153) } \\
\text { You could tell that she just knew what she was doing, very routine. She was } \\
\text { comfortable with babies. Like, she was excited. She was talking to our son. Like, } \\
\text { we hadn't even started talking to our kid. And, it was just a very, like, upbeat } \\
\text { feeling. And, she was, like, "yeah, stay in here as long as you need to" and, like, } \\
\text { just very warm...and comfortable." (035) } \\
\text { And, it was certainly my experience that everybody was sensitive... I felt } \\
\text { completely supported. And, I felt like for all I knew [she] could have been there } \\
\text { only for me; and that's the way she made you feel. Like, "I'm just here for you } \\
\text { and it doesn't matter; anybody can walk into my office right now. It doesn't } \\
\text { matter. I'm talking to you. And, I think she was great at that. And, I think if } \\
\text { your other folks are making a... are like her, I don't think you have a problem. } \\
\text { And, I mean, doctors or whoever making that call, as long as parents feel } \\
\text { supported and that you care and it's not a... this is not routine. It may be routine } \\
\text { to you; it's not routine to me. That's the only thing. (141) }\end{array}$ \\
\hline $\begin{array}{l}\text { The role of early information } \\
\text { about newborn screening } \\
\text { outcomes is unresolved }\end{array}$ & $\begin{array}{l}\text { You know, if my OB would have sat down with me and spoken to me for five, } \\
\text { ten minutes about what the results would be and, you know, potential results and } \\
\text { what would happen, what the steps would be if this or that happened; yes, the } \\
\text { pregnant woman freaks out, but it's almost... it's better to be kind of forewarned I } \\
\text { think. It gives you time to think about it. I don't know. Instead of just somebody } \\
\text { coming in and, you know, doing the prick test and then two weeks later you get a } \\
\text { phone call, ta da! (153) } \\
\text { And, I've thought a lot about this since. I'm not so sure I would have had it any } \\
\text { other way. That's kind of the problem because you kind of forget about it. But, if } \\
\text { nothing was wrong, so say with the second child, I'm not so sure I'd want to be } \\
\text { thinking about, you know, a phone call that may come. Of course I will now } \\
\text { because I've gone through it, but I'm not so sure what the right answers are. At } \\
\text { first I thought it would have been nice to be reminded when we left the hospital } \\
\text { that those... that screening was being completed, but now that I've sat and thought } \\
\text { about it I'm not so sure I would have wanted to know that either. So, I would say } \\
\text { we were completely shocked. I guess part of the problem too is when we signed } \\
\text { that form we didn't really know what was being tested either. And, you know, } \\
\text { we could have looked it up for sure and I've since looked it up, but I had no idea } \\
\text { what we were even... was the potential to come up. (050) }\end{array}$ \\
\hline
\end{tabular}

